Difference (MCID) against patient report and physician assessed anchors of changes in health. Two patient reported anchors were used (Global change in health and item 2 of Short Form 36 form). Physician assessed anchors of change in health were disease activity (Physician global assessment-PGA, SELENA-SLEDAI) and damage (SLICC-SDI/ACR). Change in PGA of $\geq 0.3$ and SELENA-SLEDAI of $>4$ in either direction was used to define worsening in disease activity. Analysis of variance was used to compare changes in LIT score against the anchors.

Results: Mean (SD) age of participants was $42(14)$ years. Ninety five percent were women. Mean (SD) PGA, SELENA-SLEDAI and SDI at baseline were 0.5 (0.5), 2.9 (3.0) and 0.7 (1.2) respectively. Mean (SD) LIT score at baseline was 27.8 (18.2). Mean changes in LIT scores in response to worsening, no change or improvement based on patient report and physician assessments are shown in Table 1. MCID for "some worsening" were -4.0 and -3.9 on patient reported health question and SF36 question 2 respectively.

Table 1: Responsiveness of LIT to patient and physician based anchors in SLE.

\begin{tabular}{|c|c|c|c|c|}
\hline \multirow[t]{2}{*}{ Anchor } & Thange & $\mathrm{N}$ & Mean Change In LIT & \multirow{2}{*}{ p-value } \\
\hline & \multicolumn{3}{|c|}{ Patlent Reported Change } & \\
\hline \multirow[t]{3}{*}{ SF3E-Q2 } & Worse & 118 & -4.7 & \multirow[t]{3}{*}{0.001} \\
\hline & No Change & 155 & 0.3 & \\
\hline & Much Better & 157 & 2.5 & \\
\hline \multirow[t]{3}{*}{ Global Change In Health Status } & Worse & 118 & -4.7 & \multirow[t]{3}{*}{$<0,001$} \\
\hline & No Charge & 155 & 0.3 & \\
\hline & Batter & 157 & 2.5 & \\
\hline \multicolumn{5}{|c|}{ Patlent Assessed Change } \\
\hline \multirow[t]{3}{*}{ PGA } & increase of 20.3 & 72 & -2.8 & \multirow[t]{3}{*}{0.02} \\
\hline & stable & 251 & -10 & \\
\hline & Decrease of 20.3 & 104 & 2.7 & \\
\hline \multirow{3}{*}{ SELENA- SLEDAI } & Increase of $z 4$ & 49 & -3.5 & \multirow[t]{3}{*}{0.005} \\
\hline & Stable & 340 & -0.6 & \\
\hline & Decrease of 34 & 41 & 6.0 & \\
\hline \multirow[t]{2}{*}{ sa } & Unchangad & 405 & 0.1 & \multirow{2}{*}{0.005} \\
\hline & Increase of $\geq 10$ & 21 & -6.7 & \\
\hline
\end{tabular}

Conclusions: LIT shows responsiveness to changes in both patient-reported and physician assessed changes in health status among Chinese SLE patients. Disclosure of Interest: None declared

DOI: 10.1136/annrheumdis-2017-eular.3941

\section{AB0484 LUPUS NEHRITIS AND PREGNANCY: MATERNAL AND FETAL OUTCOME}

P.B. Alba ${ }^{1}$, C. Otaduy ${ }^{1}$, C.A. Gobbi ${ }^{1}$, A. Alvarez ${ }^{2}$, A. Albiero ${ }^{3}$, E.H. Albiero ${ }^{1}$, M.L. Propato ${ }^{2}$, M.A. Yorio ${ }^{1}{ }^{1}$ Rheumatology, Córdoba State University;

${ }^{2}$ Rheumatology, Hospital Materno Neonatal; ${ }^{3}$ Rheumatology, Hospital Córdoba, Córdoba, Argentina

Background: Systemic lupus erythematosus (SLE) is a multisystem autoimmune disease that primarily affects women during their reproductive years. The presence of Lupus nephritis (LN) may result in an increased risk of disease flare and adverse maternal and fetal outcomes, such as preeclampsia, fetal loss, and preterm delivery

Objectives: The purpose of this work is to evaluate pregnancy outcome in SLE patients with previous diagnosis of LN.

Methods: We retrospectively studied SLE patients according 1997 ACR criteria with previous diagnosis of $\mathrm{LN}$ by renal biopsy who attended to Materno Neonatal Hospital during the last 5 years. We evaluated demographic, clinical, laboratory and obstetric data. Renal biopsies were classified according ISN/RNP 2004. Lupus activity was evaluated by modified pregnancy SELENA SLEDAI score at the conception and during pregnancy. Maternal complications were evaluated: Preeclampsia, HELLP, Gestational Diabetes, Premature Rupture of the membranes, arterial and venous thrombosis, and others. Fetal outcome was evaluated as live birth, gestational age and weight at birth.

Results: 44 pregnancies in 32 patients were included. Maternal mean age was 22,68 years old, mean duration SLE was 7.8 years and $22 \%$ had antiphospholipid syndrome (APS), $62.5 \%$ were from Córdoba city, $84.3 \%$ did not have health insurance, and they have mean previous pregnancies of 2 with 1 live birth. Maternal complications were: Pre eclampsia in $22.7 \%$ of patients, Preterm delivery in $20.45 \%$ of patients, Premature rupture of the membranes in $6.8 \%$, Gestational Diabetes in $2.27 \%$ of patients. 14 patients had normal labour, 29 cesarean section and 1 abortion. $97 \%(n=42)$ of patiens have live birth with mean gestational age of 36 weeks with mean weight at birth of $2.399 \mathrm{~g}$. and there was no maternal mortality.

Table 1. Maternal Complications

\begin{tabular}{lc}
\hline Preeclampsia & $10(22,7 \%)$ \\
Pre term delivery & $9(20,4 \%)$ \\
Premature rupture of the membranes & $3(6,8 \%)$ \\
Gestacional diabetes & $1(2,3 \%)$ \\
Mortality & 0 \\
Renal relapse & $8(18,1)$ \\
Renal Insufficiency & $2(4,5 \%)$ \\
\hline
\end{tabular}

Conclusions: SLE patients with previous LN had a good maternal and fetal outcome in this study.

References:

[1] Moroni G, Doria A, Giglio E, Tani C, Zen M, Strigini F, Zaina B, Tincani A, de Liso F, Matinato C, Grossi C, Gatto M, Castellana P, Limardo M, Meroni $\mathrm{PL}$, Messa P, Ravani P, Mosca M. Fetal outcome and recommendations of pregnancies in lupus nephritis in the 21st century. A prospective multicenter study. J Autoimmun. 2016 Nov;74:6-12. doi: 10.1016/j.jaut.2016.07.010. Epub 2016 Aug 2.

[2] Lazzaroni MG, Dall'Ara F, Fredi M, Nalli C, Reggia R, Lojacono A, Ramazzotto F, Zatti S, Andreoli L, Tincani A. A comprehensive review of the clinical approach to pregnancy and systemic lupus erythematosus. J Autoimmun. 2016 Nov;74:106-117. doi: 10.1016/j.jaut.2016.06.016. Epub 2016 Jul 2.

[3] Moroni G, Doria A, Giglio E, Imbasciati E, Tani C, Zen M, Strigini F, Zaina B, Tincani A, Gatto M, de Liso F, Grossi C, Meroni PL, Cabiddu G, Messa P, Ravani $P$, Mosca M. Maternal outcome in pregnant women with lupus nephritis. A prospective multicenter study. J Autoimmun. 2016 Nov;74:194-200. doi: 10.1016/j.jaut.2016.06.012. Epub 2016 Jun 30.

Acknowledgements: We are grateful whit Secyt subsidy UNC.

Disclosure of Interest: None declared

DOI: 10.1136/annrheumdis-2017-eular.6675

\section{AB0485 PRIMARY ANTIPHOSPHOLIPID SYNDROME: MATERNAL AND FETAL OUTCOME}

C. Otaduy ${ }^{1}$, P.B. Alba ${ }^{1}$, C.A. Gobbi ${ }^{1}$, A. Alvarez $^{2}$, A. Albiero ${ }^{3}$, E.H. Albiero ${ }^{1}$, M.L. Propato ${ }^{2}$, M.A. Yorio ${ }^{1} .{ }^{1}$ Rheumatology, Córdoba State University;

${ }^{2}$ Rheumatology, Hospital Materno Neonatal; ${ }^{3}$ Rheumatology, Hospital Córdoba, Córdoba, Argentina

Background: Antiphospholipid antibodies (APLAs) have been associated with pregnancy loss and other obstetric complications, such as pre-eclampsia, fetal growth restriction and preterm delivery.

Objectives: The purpose of this work is to evaluate maternal and fetal pregnancy outcome in Primary Antiphospholipid Syndrome (PAPS).

Methods: We retrospectively studied PAPS patients according to Sydney Criteria who are attended to Materno Neonatal Hospital during the last 8 years. We evaluated demographic, obstetric and thrombotic clinical data. Maternal complications were evaluated: Preeclampsia, HELLP, Gestational Diabetes, Premature rupture of fetal membranes, arterial and venous thrombosis, mortality, the way of end of pregnancy, and others. Fetal outcome was evaluated as live birth, gestational age and weight at birth.

Results: 96 pregnancies in 68 patients were included. Maternal mean age was 30,75 years old, $84 \%$ were from Córdoba city, $70.5 \%$ did not have health insurance, and they have mean previous pregnancies of 4 with 1 live birth. Maternal complications were: Pre eclampsia in 12 patients (12.5\%), Preterm delivery in 6 patients $(6.25 \%)$, Premature rupture of fetal membranes in 8 $(8.33 \%)$, Gestational Diabetes in $7(7.29 \%)$, Arterial Thrombosis in $2(2.08 \%)$, Venous thrombosis in $3(3.12 \%) .33,69 \%$ have normal labour and $66,33 \%$ cesarean section. $86 \%$ of patients have live birth with mean gestational age of 36 weeks with mean weight at birth of $2.558 \mathrm{~g}$ and $73 \%$ of patients according to gestational age.

Table 1. Maternal Complications

\begin{tabular}{lc}
\hline Pre Eclampsia & $12(12,5 \%)$ \\
Pre term delivery & $6(6,2 \%)$ \\
Premature rupture of fetal membranes & $8(8,2 \%)$ \\
Gestacional Diabetes & $7(7,3 \%)$ \\
Arterial Thrombosis & $2(2 \%)$ \\
Venous Thrombosis & $3(3,1 \%)$ \\
Notch & $10(10 \%)$ \\
Mortality & 0 \\
\hline
\end{tabular}

Mortality

Fetal Outcomes

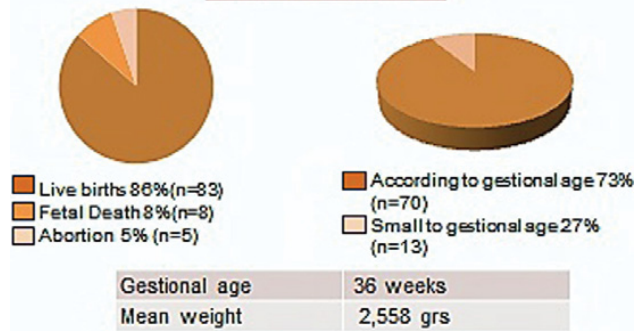

Conclusions: PAPS pregnancies patients had a good maternal and fetal outcome in this study.

References:

[1] Bertolaccini ML, Sanna G2 Recent advances in understanding antiphospholipid syndrome. F1000Res. 2016 Dec 22;5:2908. doi: 10.12688/ f1000research.9717.1. eCollection 2016.

[2] Pelusa HF, Pezzarini E, Basiglio CL, Musuruana J, Bearzotti M, Svetaz MJ, Daniele SM, Bottai H, Arriaga SM. Antiphospholipid and antioangiogenic activity in females with recurrent miscarriage and antiphospholipid syndrome.Ann Clin Biochem. 2016 Sep 16. pii: 0004563216672248. [Epub ahead of print.

[3] Moroni G, Doria A, Giglio E, Tani C, Zen M, Strigini F, Zaina B, Tincani A, de Liso F, Matinato C, Grossi C, Gatto M, Castellana P, Limardo M, Meroni 